\title{
Sistem Business Intelligence Untuk Mendukung Perguruan Tinggi yang Kompetitif
}

\author{
Mustafid* \\ Fakultas Sains dan Matematika, Universitas Diponegoro, Semarang
}

Naskah Diterima : 2 Januari 2013; Diterima Publikasi : 15 Maret 2013

\begin{abstract}
Development of higher education are not depends on the magnificent campus or laboratory equipment, but depends on the intelligence of intellectual capital management based on their resources. The role of intellectual capital is very important and strategic in business management academic programs to achieve competitive advantage. Business intelligence system as an important element in the university functioned to help manage intellectual capital in the managerial decision-making process in order to improve the performance of the university. This research aims to implement business intelligence systems to support business management academic programs towards more competitive through planning systems, and improve the performance based measurement of intellectual capital. University intellectual capital resource described by university owned, so the management of intellectual capital becomes more optimal. The use of business intelligence systems based on information technology measure aims to design, manage and develop intellectual capital, which include knowledge, skills and university human resources. The use of key performance indicators universities analyzed to satisfy quality standards of competitive university.
\end{abstract}

Keywords: Business intelligence systems; Intellectual capital; Human capital; Structural capitalal; Key performance indicators

\begin{abstract}
Abstrak
Pengembangan perguruan tinggi saat ini tidak lagi bergantung pada megahnya kampus atau peralatan laboratorium, melainkan bergantung pada kecerdasan dalam pengelolaan modal intelektual berdasarkan sumberdaya yang dimiliki. Peranan modal intelektual menjadi sangat penting dan strategis dalam pengelolaan program bisnis akademik untuk mencapai keunggulan kompetitif. Sistem business intelligence sebagai elemen penting dalam perguruan tinggi difungsikan untuk membantu manajerial mengelola modal intelektual dalam proses pengambilan keputusan dalam rangka meningkatkan kinerja perguruan tinggi. Penelitian ini bertujuan untuk mengimplementasikan sistem business intelligence untuk mendukung pengelolaan program bisnis akademik kearah yang lebih kompetitif melalui sistem perencanaan, pengukuran dan meningkatkan kinerja berbasis modal intelektual. Modal intelektual perguruan tinggi dideskripsikan berdasarkan sumberdaya perguruan tinggi yang dimiliki, agar dalam pengelolaan modal intelektual menjadi lebih optimal. Penggunaan sistem business intelligence berbasis pada teknologi informasi bertujuan untuk mendesain mengukur, mengelola dan mengembangkan modal intelektual, antara lain berupa pengetahuan, skill dan keahlian sumberdaya manusia perguruan tinggi. Penggunaan indikator kinerja kunci perguruan tinggi dianalisis untuk memenuhi standar mutu perguruan tinggi yang kompetitif.
\end{abstract}

Kata kunci: Sistem business intelligence; Modal intelektual; Modal sumberdaya; Modal struktural; Indikator kinerja kunci

\section{Pendahuluan}

Business Intelligence (BI) merupakan elemen penting dalam pengelolaan modal intelektual dan proses pengambilan keputusan untuk membantu para pimpinan dan manajer untuk meningkatkan kinerja perguruan tinggi (PT). Saat ini, pengembangan sains dan teknologi pada PT berbasis pembangunan ekonomi kontemporer sudah seharusnya lebih fokus berbasis pada modal intelektual berdasarkan sumberdaya yang dimiliki. Modal intelektual di PT menjadi penting dan strategis untuk mencapai keunggulan kompetitif sesuai dengan visi, misi dan

\footnotetext{
*) Penulis korespondensi: mustafid55@yahoo.com
}

tujuan PT karena berhubungan langsung dengan daya saing. Peran utama PT saat ini adalah untuk menciptakan pengetahuan baru yang dapat melahirkan inovasi dari tenaga akademik dan mahasiswa, baik inovasi dalam proses pembelajaran, penemuan sain maupun teknologi. Inovasi didasarkan pada informasi dari proses pengetahuan pada berbagai jenis bidang ilmu.

Peranan BI dalam manajemen PT adalah untuk mengoptimalkan kinerja proses bisnis akademik dengan mendorong penggunaan modal intelektual yang efektif dan efisienl (Golfarrelli, 2005). Penerapan business intelligence secara umum untuk 
mengukur kinerja dari bisnis akademik berdasarkan potensi PT, dapat digunakan untuk mendesain, mengelola dan mengukur kinerja PT (Elbashir et al., 2008, Muntean et al., 2009.). Metode pengukuran kinerja PT diperlukan sebagai dasar untuk pengembangan strategi, rencana aksi, program dan kegiatan perbaikan terus-menerus. Metode pengukuran kinerja juga digunakan untuk mengukur kinerja, memantau situasi aktual dan merencanakan perbaikan kinerja dimasa yang akan datang.

Penelitian ini bertujuan untuk mengimplementasikan sistem business intelligence untuk mendukung pengelolaan perguruan tinggi kearah yang lebih kompetitif melalui sistem perencanaan, pengukuran dan meningkatkan kinerja berbasis pada pengelolaan modal intelektual. Sistem Business Intelligence (SBI) dirancang berbasis web dengan metode On-Line Analytical Processing (OLAP). Penggunaan indikator kinerja kunci PT didesain untuk memenuhi standar mutu nasional, internasional dan global. Sebagai input data pada SBI berasal dari berbagai data transaksional dosen, staf adminitrasi, mahasiswa, termasuk aspek administrasi keuangan. SBI dalam sistem informasi akademik diformulasikan dalam indikator kinerja kunci akademik (IKK) PT yang menjadi salah satu tolok ukur penting untuk mencapai tingkat keberhasilan PT.

\section{Peranan Business inteligence di PT}

Business Intelligence (BI) memiliki peranan yang sangat penting dalam pengambilan keputusan untuk membantu para manajer dan pimpinan PT untuk meningkatkan kinerja PT (Muntean et al,, 2009). BI merupakan komponen penting bagi PT yang berfungsi untuk mengukur, memantau dan mengelola kinerja PT secara lebih efektif. Pengembangan PT saat ini seharusnya didasarkan pada modal intelektual. Modal intelektual sebagai aset PT menjadi penting dan strategis untuk mencapai keunggulan kompetitif sesuai dengan visi, misi dan tujuan PT. Penerapan BI diarahkan untuk mengukur kinerja dari proses bisnis akademik berdasarkan susmberdaya dan potensi yang dimiliki oleh PT. Penerapan BI bertujuan untuk mengumpulkan data, menyimpan data, menganalisis data dan menyediakan akses ke data, sehingga dapat membantu manajemen dalam pengambilan keputusan secara akurat dengan melakukan berbagai aktivitas PT untuk menyiapkan perencanaan strategis universitas ke depan.

Faktor utama yang harus diperhatikan oleh pimpinan PT dalam meningkatan daya saing adalah kemampuan sumberdaya manusia PT untuk mengukur daya saing PT berdasarkan kebutuhan pengguna lulusan, layanan akademik, dan keunggulan PT pesaing. Analisis penggunaan BI berfungsi untuk membuat perencanaan strategis berdasarkan kemampuan sumberdaya manusia yang dimilki dengan membandingkan kualitas PT lainnya yang berbeda.

Lembaga Senat di PT misalnya, merupakan lembaga normatif yang merumuskan visi, misi dan tujuan berdasarkian hasil analisis BI, dan menjabarkan dalam bentuk kebijakan PT untuk melakukan operasional berdasarkan modal intelektual yang dimiliki. Untuk melihat hasil kinerja, PT menggunakan BI sebagai sarana untuk membuat ukuran kinerja dan sekaligus sebagai parameter evaluasi ukuran kinerjanya. Ukuran kinerja PT harus didasarkan pada strategi dan analisis proses bisnis akademik kunci yang diperlukan untuk mencapai kinerja yang telah ditetapkan. Ukuran kinerja didesain dalam bentuk metrik kinerja dengan format yang intuitif untuk mendukung proses bisnis dan manajemen PT. Fungsi dasar dari metrik kinerja adalah untuk membantu dalam menentukan seberapa baik kinerja PT dan organ didalamnya. IKK PT ditetapkan untuk setiap proses bisnis akademik berdasarkan sasaran kinerja secara menyeluruh. Pemantauan metrik kinerja utama berdasarkan ukuran IKK menjadi sangat penting dalam pengelolaan PT.

Dalam perspektif sistem informasi, PT memiliki banyak pengguna SBI yang berhubungan dengan manajerial, operasional dan layanan didalam PT, antara lain pimpinan PT dan organ didalamnya, staf akademik, staf administrasi, mahasiswa, pengguna lulusan dan layanan PT. Setiap pengguna tersebut memiliki peran dan fungsi yang berbeda dalam menggunakan analisis BI untuk proses pengambilan keputusan dalam operasional bisnis akademik. Setiap pengguna SBI juga membutuhkan informasi dan data yang berbeda pula.

\section{Sistem Busines Intelligence di PT}

Kerangka SBI dapat dilihat dari tiga kategori, yaitu definisi dari aspek manajemen, teknologi, dan produk (Laudon dan Laudon, 2012). Dari perspektif manajerial, SBI dipandang sebagai proses pengadaan, pengolahan dan analisis data dari sistem internal dan eksternal. Dari perspektif teknologi, kerangka SBI dipandang dari segi peralatan, software, dan teknologi yang dapat membantu pengambil keputusan untuk mencari, mengumpulkan, mengatur, dan akses informasi dari sumber data yang berbeda. Sedangkan dari perspektif pendekatan produk, BI dipandang sebagai produk atau hasil pengolahan proses data atau informasi dan pengetahuan, dan menggunakan metode analisis untuk mendukung pengambilan keputusan dan penilaian kinerja.

Integrasi dari tiga katagori, SBI dapat didefinisikan sebagai kumpulan dari arsitektur enterprise terintegrasi dalam bentuk aplikasi berfungsi untuk mendukung operasional dan membuat keputusan bagi berbagai pemangku 
kepentingan bisnis dengan akses mudah mudah, cepat dan tepat ke informasi yang diperlukan (Gambar 1).

Infrastruktur terintegrasi pada BI menyiapkan arsitektur informasi dengan menjamin efisiensi dan kelincahan operasional manajerial PT untuk menghadapi kebutuhan bisnis dan adanya perubahan yang bergerak cepat (Gambar 1). Infrastruktur informasi meliputi gudang data, data mart, penyimpanan data operasional, dan data warehouse real-time. Manajemen PT membutuhkan data warehouse sebagai sumber informasi terpusat bagi semua sumber daya PT yang diperlukan untuk operasional manajerial untuk pelaporan, analisis dan pengembangan rencana strategis $\mathrm{PT}$, dan mendukung kegiatan analisis mengenai program bisnis akademik utama, yaitu pendidikan, penelitian, pengabdian kepada masyarakat, dan manajemen PT.

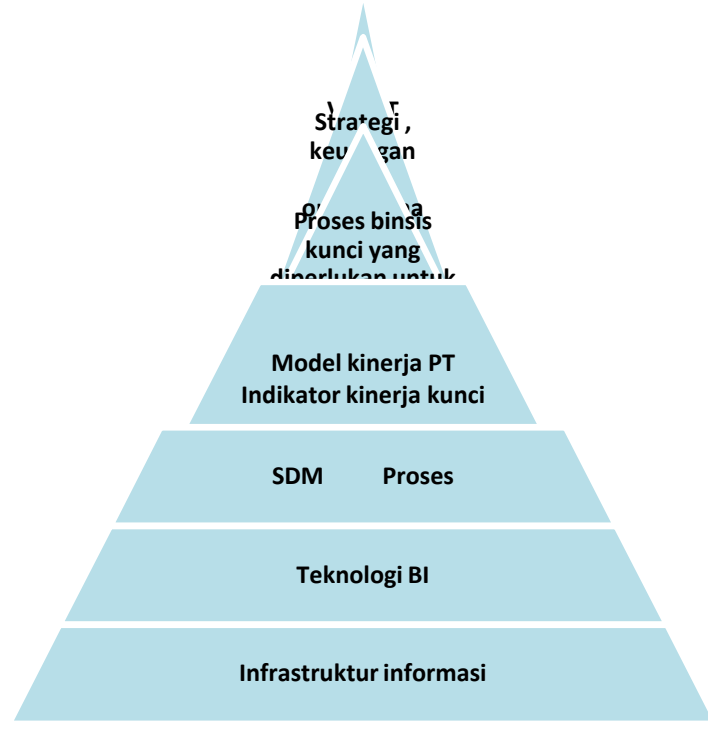

Gambar 1. Kerangka BI pada PT

Sumber : Muntean et.al., (2009), disesuaikan

SBI pada PT dirancang berbasis web dengan metode On-Line Analytical Processing (OLAP) bertujuan untuk menghasilkan rancangan arsitektur data warehouse akademik. Sebagai input data warehouse berasal dari berbagai data transaksional dosen, staf adminitrasi, mahasiswa, termasuk aspek keuangannya. Input data tersebut meliputi data dosen dan aktivitasnya, data hasil pembelajaran mahasiswa, layanan mahasiswa, hasil penelitian dan pengabdian kepada masyarakat, alokasi sumber daya, e-learning. Input data juga termasuk input data dari sumber eksternal seperti data kebutuhan tenaga kerja, kompetensi dosen, kompetensi mahassiwa yang dibutuhkan oleh pengguna, dan kinerja PT lain. SBI menggunakan pusat penyimpanan data (data storage center) yang dikelola oleh bagian teknologi informasi dan komunikasi. Pusat penyimpanan data berfungsi juga untuk proses penyimpanan dan pengelolaan data berupa data pegawai, dosen, mahasiswa, kegiatan pembelajaran, penelitian dan pengabdian pada masyarakat, kepustakaan, keuangan, alumni dan lainnya.

SBI menyediakan sumber data yang terpusat, sehingga dapat di akses di seluruh organ PT. Dengan SBI ini, unit penyedia informasi dapat dengan cepat menganalisa permasalahannya, dan selanjutnya segera dengan cepat pula memperoleh hasil keputusan yang tepat sasaran. SBI berperan mengolah data dari data warehouse, dan menggunakan konsep OLAP untuk menyajikan informasi yang diperlukan dalam peningkatan kualitas PT melalui perencanaan strategis (Dell'Aquila et al., 2008). Arifin et al. (2012) mendesain SBI universitas menggunakan lima komponen dasar, yaitu data source, data integrasi, data warehouse, data analisis, dan web portal. Penerapan SBI tersebut menghasilkan output sistem dalam bentuk dashbord untuk menampilkan hasil kinerja PT berdasarkan kriteria dari BAN-PT.

SBI dalam sistem informasi akademik diformulasikan dalam indikator kinerja akademik PT yang menjadi salah satu tolok ukur penting untuk mencapai tingkat keberhasilan PT. Penggunaan teknologi dan sistem informasi membawa kualitas manajemen PT yang dapat mempengaruhi kualitas di berbagai aspek penilaian PT, baik secara internal maupun eksternal. SBI pada PT memberi banyak peran pada sistem pendukung keputusan dalam lingkungan akademik, manajemen sumberdaya dan manajemen keuangan serta untuk pengembangan sesuai dengan perencanaan strategis PT. SBI juga digunakan sebagai sistem untuk mempertimbangkan dalam proses pengambilan keputusan pada PT, dengan melibatkan sejumlah faktor yang mempengaruhi pengelolaan PT sebagaimana dalam manajemen bisnis pada perusahaan umum. Dalam SBI dilengkapi sarana untuk melakukan pengelolaan dan penyajian informasi secara cepat, akurat, menarik, dan mempunyai nilai bisnis sebagai penunjang pengambilan keputusan.

\section{Modal Intellektual di PT}

Sumber daya utama dan strategis dalam BI di PT adalah modal intelektual. Modal intelektual merupakan modal dasar dalam BI untuk pencapaian visi PT, dan sekaligus merupakan dasar keberlangsungan operasional PT. Pengembangan modal intelektual yang berkualitas memainkan peran penting dalam memperkuat standar pendidikan dan penelitian pada suatu PT. Modal intelektual tidak hanya sebagai modal sumber masukan bagi PT, tetapi juga merupakan hasil pengembangan modal intelektual berupa produk pendidikan, penelitian dan pengabdian kepada masyarakat. PT yang memiliki modal intektual yang unggul akan berdampak pada 
kualitas pendidikan dan penelitian yang kompetitif sebagai faktor utama daya tarik bagi mahasiswa dan masyarakat.

Modal intelektual telah dirujuk sebagai kekayaan baru dari suatu PT yang memiliki kemampuan untuk mentransformasikan pengetahuan dan aset tidak berwujud (intangible) menjadi kekayaan untuk menciptakan sumber daya organisasi (Edvinsson, 2002). Organisasi yang mengelola modal intelektual secara efektif harus memperhatikan pada beberapa aspek :

a. Manajemen dan pengukuran modal intelkutal.

b. Sistem penilaian modal intelektual.

c. Sistem kekayaan intelektual.

Untuk mendeskripsikan bagaimana modal intelektual dapat berkontribusi pada peningkatan kinerja PT yang kompetitif, beberapa penulis membuat definisi modal intelektual yang berbedabeda. Edinsson and Malone (1997) menjabarkan modal intelektual menjadi modal manusia dan modal struktural (Gambar 2.). Modal manusia meliputi karakter PT, yaitu antara lain etika PT, filosofi, budaya, dan juga meliputi kreatifitas, kompetensi dan skill. Sedangkan modal struktural dibedakan menjadi modal organisasi dan modal pelanggan. Untuk modal organisasi mencakup sumberdaya inovasi dan sumberdaya proses.

Modal manusia merupakan gabungan pengetahuan (knowledge), keterampilan (skill), inovasi, dan kemampuan individu yang dimiliki oleh sumberdaya manusia PT untuk menjalankan tugas pendidikan, penelitian dan pengabdian kepada masyarakati. Modal manusia sebagai sumberdaya juga berupa tata nilai, budaya dan filosofi. Modal manusia dimiliki oleh setiap sumberdaya manusia di PT. Modal manusia merupakan jiwanya PT yang merupakan pengetahuan tacit individu yang dimiliki PT. Bontis et al. (1999) mengidentifikasi tiga jenis modal manusia :

a. Kompetensi berdasarkan skill dan pengetahuan.

b. Sikap yang tercermin dalam tingkat motivasi pada PT dan kualitas manajemen dalam kepemimpinan.

c. Kelincahan intelektual sebagai kemampuan individu dalam PT untuk berinovasi, beradaptasi dan menumbuhkembangkan.

Modal manusia merupakan sumber pembaharuan dan inovasi. Esensi dari modal manusia terletak pada kecerdasan dan kecerdikan sumberdaya manusia dalam menjalankan tugas program bisnis akademik. Modal manusia merupakan sumber inovasi melalui kemampuan individu, meliputi pengetahuan, skill, pengalaman, termasuk pengalaman institusi dan kemampuan problem solving dari sumberdaya manjusia di PT (Sullivan, 2000). Modal manusia sangat berkaitan dengan kompetensi individu sumberdaya manusia (dosen, tenaga kependidikan dan mahasiswa). Modal manusia dari dosen dan mahasiswa merupakan aspek yang paling cepat berkembang, khususnya dalam bidang pendidikan dan penelitian. Pengembangn modal manusia tersebut hendaknya dilakukan melalui kerjasama dalam bentuk kolaborasi dengan masyarakat pengguna PT dan lulusan. Sehingga dosen dan mahasiswa mendapatkan akses dengan skill dan kompetensi sesuai dengan daya saing nasional, internasional atau global.

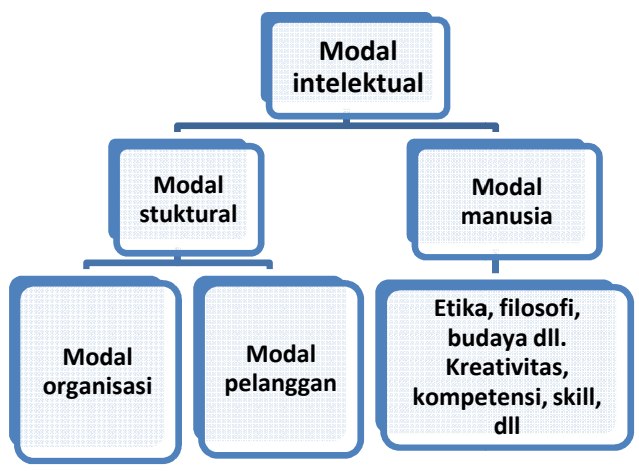

Gambar 2. Modal intelektual

Modal struktur dapat didefinisikan sebagai perangkat lunak, database, struktur organisasi, paten, dan merek dagang. Modal struktural merupakan modal dari segala sesuatu infrastruktur yang dimiliki oleh PT untuk mendukung produktivitas aktivitas sumberdaya manusia. Modal struktural pada aspek lain mencakup aset organisasi berupa aset infrastruktur yang terkait dengan teknologi, metodologi, manajemen dan proses yang memungkinkan organisasi PT untuk berfungsi, yang pada gilirannya memungkinkan PT dapat menghasilkan nilai dari proses pembelajaran. Modal struktural sebagai aset digunakan untuk kegiatan operasional, pengembangan dan inovasi dengan fokus pada pendidikan, penelitian dan pengembangan, pengabdian kepada masyarakat dan hak kekayaan intelektual, di mana semuanya memberikan kontribusi untuk menghasilkan produk dan layanan PT.

Modal struktural juga melibatkan modal pengembangan dan inovasi. Modal struktural ini merupakan prasyarat untuk inovasi, kreativitas dan daya cipta dan yang relevan dengan kebijakan inovasi (Bontis et al., 1999). Modal pengembangan dan inovasi meliputi :

a. Pembelajaran (learning), adanya kebebasan individu sivitas akademika (dosen, mahasiswa, dan manajer) untuk belajar sesuai dengan bidang ilmunya.

b. Pengolahan pengetahuan (knowledge processing), kebijakan yang menentukan sejauh mana sivitas akademika menciptakan, berbagi, dan menerapkan pengetahuan baru, serta berbagi manfaat dari pengetahuan mereka dengan sesama. 
c. Keterhubungan (connectedness), interaksi dan hubungan antar sivitas akademika melalui infrastruktur teknologi dan jaringan sosial.

d. Ethodiversity, kebijakan yang menentukan keragaman etos organisasi, termasuk tata nilai dan cara pandang dalam upaya untuk belajar, berinovasi dan beradaptasi.

Dalam perpektif manajemen, modal intelektual merupakan aset berharga yang harus dipertahankan dan dikembangkan dari waktu ke waktu, dan pada setiap tahapan harus dapat diambil keuntungan berupa pengetahuan baru. Dalam pandangan ini ada dua pendekatan dasar dalam menciptakan pengetahuan baru berupa inovasi, yaitu :

a. Inovasi sebagai strategi bisnis akademik. Ini berfokus pada pengelolaan modal intelektual untuk kegiatan yang produktif dalam bidang akademik dengan penggunaan teknologi dan keunggulan kompetitif. Pendekatan ini menekankan pentingnya pemahaman terhadap kebutuhan stakeholder dalam program pendidikan, riset dan pengembangan.

b. Manajemen pembelajaran dan penciptaan pengetahuan. Ini berfokus pada manajemen pendidikan yang kreatif, membuat mereka lebih efektif dan fleksibel dalam berkarya di bidang pendidikan dan penelitian.

Selanjutnya, modal struktural dapat berupa modal pelanggan yang berfungsi untuk memproyeksikan citra positif dan kemampuan untuk menarik masyarakat dan mahasiswa yang potensial. Modal pelanggan harus didukung dengan penggunaan teknologi modern, hasil penelitian yang berkualitas, program pendidikan yang relevan, manajemen strategis partisipatif visioner, kepatuhan terhadap misi, dan kesehatan keuangan, serta kesehatan institusi. PT harus dapat melihat perkembangan dan kebutuhan masyarakat di luar kampus (dunia bisnis, industri dan pemerintahan) pada tingkatan lokal, nasional maupun global. Kerjasama lokal, nasional dan internasional harus menjadi prioritas bagi PT dalam rangka mengembangkan modal intelektual PT. BI melalui manajemen pengetahuan berkontribusi untuk pengembangan modal intelektual dengan mengikuti tren globalisasi sesuai dengan keinginan stakeholder yang berdampak pada peningkatan daya saing PT, yang pada akhirnya akan meingkatkan kualitas PT yang kompetitif.

\section{Pengukuran kinerja PT}

Pengelolaan BI mengunakan sistem terpadu yang melibatkan semua aspek sumberdaya di PT. Pengelolaan BI initinya adalah mengelola modal intelektal berdasarkan sumbedaya yang dimiliki oleh PT. Salah satu aspek pengelolaan BI tersebut adalah mengunakan manajemen kinerja bisnis akademik (MKBA) untuk perencanaan, pengelolaan dan peningkatan kinerja PT. MKBA didefinisikan sebagai serangkaian proses yang membantu manajemen PT dalam perencanaa, pengelolaan, pengukuran, analisis dan peningkatan kinerja bisnis akademik dengan mengoptimalkan kinerja dengan mendorong penggunaan secara efektif dan efisien sumber daya keuangan, manusia dan material (Golfarelli et al 2004). MKBA termasuk juga pada aspek manajemen seperti perencanaan keuangan, perencanaan operasional, konsolidasi dan pelaporan, pemodelan bisnis, analisis, dan pemantauan indikator kinerja utama terkait dengan strategi PT. MKBA memungkinkan PT dapat menyelaraskan kegiatan operasional akademik dengan tujuan untuk meningkatkan kinerja melalui pengambilan keputusan yang tepat sasaran. MKBA juga didefinisikan sebagai sistem real-time, bahwa manajer waspada terhadap peluang potensial, masalah akan muncul, dan ancaman, dan kemudian memberdayakan mereka untuk bereaksi melalui model dan kolaborasi.

Metodologi pengukuran kinerja bisnis akademik untuk pengembangan PT, dilakukan dengan strategi, rencana aksi, program dan kegiatan perbaikan terusmenerus, dengan memantau situasi aktual dan waktu yang akan datang. Aplikasi MKBA meliputi aspek proses manajemen dan analisis, didukung oleh teknologi yang memungkinkan PT dapat menetapakan tujuan strategis, kemudian mengukur, mengelola dan meningkatan kinerja sesuai dengan visi, misi dan tujuan PT.

MKBA memudahkan bagi pelaku manajemen PT untuk memasok akses informasi dengan mudah kepada yang mereka yang memerlukan. Sehingga operasional akademik dapat dilakukan secara efektif, dan manajemen memiliki kemampuan untuk mengukur dan menganalisa kinerjanya. Salah satu peralatan yang digunakan pada MKBA adalah metrik kinerja akademik, berupa alat strategis untuk isian dalam penetapan tujuan, mengukur kemajuan, penghargaan prestasi, dan menampilkan hasilnya untuk melihat tingkat produktivitas PT. Metrik kinerja akademik digunakan oleh unsur pimpinan PT untuk memantau dan mengkomunikasikan tujuan strategis yang disesuaikan dengan masing-masing individu, dan peran dalam organisasi. Manajer PT menggunakan metrik kinerja akademik untuk mengidentifikasi rencana dan prestasi kinerja secara individu atau bagian. Karyawan menggunakan metrik kinerja akademik untuk panduan operasioanl dalam melaksanakan tugas-tugas meraka dalam mencapai tujuan sesuai yang telah ditetapkan.

\section{Indikator kinerja kunci PT}

Indikator kinerja kunci (IKK) PT merupakan ukuran kinerja menggunakan indikator yang memberikan informasi pencapaian hasil karya yang dihasilkan sesuai dengan sasaran strategis yang ditetapkan berdasarkan visi, misi dan tujuan PT. IKK 
PT merupakan target sasaran yang disusun berdasarkan rencana strategis dan rencana tahunan dengan menetapkan indikator kinerja yang jelas, spesifik dan terukur. IKK PT merupakan indikator kunci yang mempresentasikan kinerja PT secara keseluruhan. Jumlah indikator kinerja yang dipilih sebagai IKK ini disesuaikan dengan keperluan untuk dapat mengukur indikator kinerja utama. Hasil pengukuran melalui indikator tersebut dapat digunakan untuk menilai tingkat keberhasilan PT dalam mencapai tujuan dan sasaran yang telah ditetapkan.

Dalam aplikasi BI pada PT, manajemen harus berfokus pada modal intelektual untuk mengidentifikasi dan mengumpulkan pengetahuan dan skill sumberdaya manusia (Dosen dan tenaga kependidikan) untuk meningkatkan daya saing PT. PT dengan modal intelaktual harus fokus pada kekuatan pasar eksternal untuk memungkinkan PT dapat memahami dinamika pasar, sehingga posisi PT dapat mengelola modal intelektual secara optimal untuk meningkatkan daya saing PT.

Survei dan riset pelanggan pengguna jasa PT menjadi bagian penting dalam pengembangan modal intelektual. Metode analisis (statistika dan matematika) dalam sistem BI digunakan untuk memandu PT dalam mengembangkan pengetahuan disesuaikan dengan modal intelektual dan skill staf manajer dan kebutuhan pengguna. Pengetahuan dan skill yang telah dimiliki harus selalu dikembangkan, dan peran SBI di PT dapat mengelola informasi dalam kerangka sistem informasi, dan membantu individu sumberdaya manusia dalam upaya PT untuk mengembangkan modal intelektual yang lebih cerdas, dan dapat membuat keputusan yang tepat dan cepat.

Penilaian kinerja PT di Indonesia didasarkan pada sistem penjaminan mutu PT menggunakan beberapa model sistem mutu, antara lain sstem penjaminan mutu yang dikeluarkan oleh Kemdiknas, ISO 9001:2008, Malcolm Balridge National Quality Award (MBNQA) (Ditjen Dikti, Kementerian Pendidikan Nasional, 2010). Beberapa PT bahkan sudah menggabungkan sistem mutu dengan menerapkan ISO 9001:2008 dan MBNQA, di samping sistem penjaminan mutu Kemdiknas yang diakreditasi melalui Badan Akreditasi Nasional Perguruan Tinggi (BAN-PT) yang merupakan kewajiban bagi semua PT di Indonesia. Sementara itu beberapa PT lain menggunakan ISO 9001:2008 sebagai basis manajemen dari sistem penjaminan mutunya, di samping sistem penjaminan mutu Kemdiknas. Penerapan SBI untuk mengukur kinerja universitas menggunakan kriteria dari BAN-PT diberikan oleh Arifin et al. (2012).

Secara umum sistem penjaminan mutu Kemdiknas, yaitu penjaminan mutu internal oleh PT dan penjaminan mutu eksternal melalui akreditasi BAN-PT, dan sistem mutu ISO 9001:2008, dan
MBNQA mempunyai kelebihan dan kelemahan masing-masing. Oleh karena itu, beberapa PT besar menggabungkan beberapa sistem penjaminan mutu tersebut agar menghasilkan penjaminan mutu yang maksimal di PT tersebut.

Tabel 1. Kerangka sistem evaluasi

\begin{tabular}{lll}
\hline $\begin{array}{l}\text { Input modal } \\
\text { intelektual }\end{array}$ & $\begin{array}{l}\text { Proses evaluasi } \\
\text { kinerja }\end{array}$ & Dampak \\
\hline $\begin{array}{l}\text { Indikator modal } \\
\text { intelktual }\end{array}$ & Kriteria evaluasi & \\
Modal manusia & Administrasi & Stakeholder \\
Modal organisasi & Kurikulum & Kementerian \\
Modal relasi & Transfer teknologi & Mahasiswa \\
& Riset & Industri \\
& Pengajaran & Publik \\
& Pelayanan & Masyarakat dll \\
\hline
\end{tabular}

Sumber : Lee (2010), disesuaikan.

Kriteria penilaian kinerja PT secara umum diberikan diberikan pada Tabel 2.

Tabel 2. Kriteria penilaian kinerja PT

\begin{tabular}{ll}
\hline Kriteria & Deskripsi \\
\hline Administrasi & $\begin{array}{l}\text { Efisiensi, efektifitas, dan produktifitas } \\
\text { pengelolaan administrasi } \\
\text { Pengembangan skill staf administrasi }\end{array}$ \\
Kurikulum & $\begin{array}{l}\text { Desain kurikulum berdasarkan kebutuhan } \\
\text { pengguna lulusan }\end{array}$ \\
& Kompetensi mahasiswa/ lulusan \\
Transfer sain dan & $\begin{array}{l}\text { Efektifitas manajemen pengetahuan } \\
\text { terhadap inovasi sains dan teknologi }\end{array}$ \\
teknologi & Komersialisasi riset dan income riset \\
& Kualitas dan kuantitas publikasi \\
Penelitian & Outcome penelitian ( paten, lisensi, dll) \\
Pembelajaran & $\begin{array}{l}\text { Berorientasi profesional } \\
\text { Karakter mahasiswa }\end{array}$ \\
Pelayanan & Pelayanan mahasiswa : \\
mahasiswa & perpustakaan dan IT \\
& Bimbingan dan konsultasi \\
Pengabdian & Kualitas dan kuantitas layanan teknologi \\
kepada & kepada masyarakat. \\
masyarakat & Outcome : penerapan teknologi
\end{tabular}

Sistem evaluasi penilaian kineja PT yang maju menggunakan sistem mereka masing-masing negara, misalnya PT di Taiwan menggunakan HEEACT (the Higher Education Evaluation and Accreditation Council of Taiwan). Kerangka konsep sistem evaluasi berdasarkan modal intelektual, kinerja dan dampak (Lee, 2010), seperti diberikan pada Tabel 1.

Untuk memenuhi standar PT kelas dunia, diperlukan kriteria PT untuk memenuhi standar mutu dengan pengakuan dunia. PT dapat menggunakan kriteria global ranking universitas, antara lain dengan Time Higher Education Supplement, Shanghai Jiao Tong World Universities Ranking, Webometrics Ranking of World Universities (Badat, 2010). Masing-masing kriteria rangking PT, menggunakan persyaratan yang sangat ketat.

Kinerja PT merupakan ukuran standar kinerja dari hasil program bisnis akademik sesuai dengan sasaran indikator kunci. Hasil pencapaian standar kinerja 
dinyatakan dalam IKK PT. Kinerja tinggi dapat diperoleh melalui motivasi, kompetensi dan kinerja sumber daya manusia berdasarkan modal intelektual. Kompetensi meliputi pengetahuan dan skill untuk menunjukkan kinerja yang tinggi dari sivitas akademika. Manajer mengelola semua modal intelektual dari sumberdaya yang dimiliki untuk dilibatkan dalam operasional dan pengembangan akademik secara optimal sesuai dengan visi, misi dan tujuan PT. Kinerja tinggi sebagai hasil dari program akademik PT dapat meliputi:

a. Produktivitas dan efisiensi,

b. Memenuhi target sesuai dengan indikator kinerja utama,

c. Menghasilkan keuntungan akademik.

Untuk mencapai kinerja tinggi, perlu kombinasi yang tepat dari semua sumberdaya dan modal intelektual, sistem, dan struktur organisasi untuk mengelola penggunaan penuh sumber daya PT, dan perhatian terhadap peluang dalam mencapai tujuan program bisnis akademik. BI menganalisis semua sumberdaya manusia yang potensial dalam bentuk modal intelektual, seperti pengetahuan dan skill yang akan diarahkan untuk mencapai keunggulan kompetitif PT.

\section{Kesimpulan}

Pengembangan PT menuju perguruan tinggi yang kompetitif harus dapat mengelola sumber daya modal intelektual. SBI digunakan sebagai elemen penting dan strategis dalam proses pengambilan keputusan untuk membantu para pimpinan dan manajer PT tinggi untuk meningkatkan kinerja PT. SBI berbasis pada teknologi informasi dan perangkat lunak digunakan untuk mengukur, mengelola dan mengembangkan pengetahuan dan keahlian sumberdaya Perguruan tinggi sebagai modal intelektual.

Untuk mencapai kinerja tinggi, perlu kombinasi yang tepat dari semua sumberdaya dan modal intelektual, sistem, dan struktur organisasi untuk mengelola penggunaan penuh sumber daya PT, dan perhatian terhadap peluang dalam mencapai tujuan program bisnis akademik. BI menganalisis semua sumberdaya manusia yang potensial dalam bentuk modal intelektual, seperti pengetahuan dan skill yang akan diarahkan untuk mencapai keunggulan kompetitif PT.

\section{Ucapan terima kasih}

Penelitian ini dilakukan menggunakan dana DIPA Universitas tahun 2012 alokasi Program Studi Magister Sistem Informasi Program Pascasarjnana Universitas Diponegoro berdasarkan SK Nomor 892/UN7.4/SK/2012. Peneliti mengucapkan terima kasih kepada Direktur Program Pascasarjana dan Ketua Program Studi Sistem Informasi Universitas Diponegoro.

\section{Daftar Pustaka}

Arifin, Z., Mustafid, Sugiharto, A., 2012. Rancang Bangun Sistem Business Intelligence Universitas Sebagai Pendukung Pengambilan Keputusan Akademik. Accepted to Jurnal Sistem Informasi Bisnis.

Badat, S., 2010. Global Ranking of Universities. www.iau-aiu.net/ conferences/ pdf/WSSF.

Bontis, N., 1998. Intellectual capital: An exploratory study that develops measures and models. Management Decision, 36(2): 63-76.

Edvinsson, L. and Malone, M.S., 1997. Intellectual Capital. Harper Collins Publishers Inc., New York.

Elbashir, M.Z., Collier, P.A., Davern, M.J., 2008. Measuring the effects of business intelligence systems: The relationship between business prosess and organizational performance. Int. Journal of Accounting Information Systems, 9, 135-153.

Dell'Aquila, C., Di Tria, F., Lefons, E., and Tangorra, F., 2008. Business intelligence applications for university decision makers, WSEAS Transactions on Computers, vol.7, no.7.

Ditjen Dikti, Kementerian Pendidikan Nasional, 2010. Sistem Penjaminan Mutu Perguruan Tinggi (SPM-PT).

Edvinsson, L., 2002. Corporate Longitude. London: Pearson Education.

Edvinsson, L. and Malone, M.S., 1997. Intellectual Capital. Harper Collins Publishers Inc., New York.

Golfarrelli, M. 2005. New Trends in Business Intelligence. Proceedings of the 1st International Symposium on Business Intelligent Systems, Opatija, Croatia, 15-26.

Laudon, K.C., Laudon, J.P., 2012. Management information systems : Managing the digital firm. Pearson edition.

Lee, S. H., 2010. Using fuzzy AHP to develop intellectual capital evaluation model for assessing their performance contribution in a university. Expert Systems with Applications, Vol. 37: 4941-4947

Muntean, M., Bologa, A-R, Bologa R., Florea A., 2009. Business Intelligence Systems in Support of University Strategy, Proceedings of the 7th WSEAS/IASME International Conference on Educational Technologies, EDUTE '11, pp.118123

Sullivan, P.H., 2000. Value-driven intellectual capital: how to convert intangible corporate assets into market value. New York: John Wiley. 